\title{
Sensitivity analysis of the mathematical model of catalytic reforming of gasoline ${ }^{1}$
}

\author{
L. F. Safiullina ${ }^{12}$, I. M. Gubaydullin ${ }^{23}$, K. F. Koledina ${ }^{23}$, R Z. Zaynullin ${ }^{2 * *}$ \\ ${ }^{1}$ Bashkir State University, Ufa, Russian Federation \\ ${ }^{2}$ Ufa State Petroleum Technological University, Ufa, Russian Federation \\ ${ }^{3}$ Institute of Petrochemistry and Catalysis of RAS, Ufa, Russian Federation
}

Detailed kinetic model is required to study one of the most important oil refining processes, which is catalytic reforming. The difficulty arises in connection with a large number of components of the reaction mixture and a large number of stages of chemical transformations in developing the kinetic model. The conversion scheme of catalytic reforming of gasoline includes 171 stages. The individual components are combined in 37 groups belonging to the following classes: normal paraffins, isoparaffins, five-membered naphthenes, six-membered naphthenes and aromatic hydrocarbons. An alternative may be reduced reaction mechanisms that are applicable to solve the problem and provide realistic description of the process. In this paper, the sensitivity analysis technique of the mathematical model was used. It was developed by the authors to obtain a reduced mechanism. The new technique has been developed for analyzing complex kinetic schemes and reducing kinetic models to sizes acceptable from the point of view of accuracy of description and ease of practical use. In this work, the global Sobol method was used to obtain a reduced model of catalytic reforming of gasoline. The model parameters were determined by a global analysis of the sensitivity of the functional of the mathematical model to the variation of the rate constants of the stages. The least influential stages of catalytic reforming of gasoline were revealed. The influence of the exclusion of these stages on the kinetics of the process from the chemical point of view is investigated. The reduced scheme for the catalytic reforming of gasoline is proposed. It provides quite satisfactory agreement both in temperature profiles and in concentration profiles of significant substances. Keywords: catalytic reforming, mathematical model, chemical kinetics, sensitivity analysis, reduced model.

Introduction. The catalytic reforming process is the most important oil refining process in Russia. It can solve the problem of increasing the octane number of gasoline and producing aromatic hydrocarbons as an important raw material for petrochemicals. Potential area for finding the solution to the aforementioned problem is catalytic reforming itself, namely, the reactor unit [1]. The most promising solution is to optimize the operation of the reactor block, which requires detailed kinetic model of the process based on the fundamental laws of flow that describes the basic laws of chemical

\footnotetext{
${ }^{1}$ The reported study was funded by RFBR, project number 19-37-60003

** E-mail: Nurislamova_LF@mail.ru, IrekMars@mail.ru, koledinakamila@mail.ru,zaynullin_ravil@outlook.com
} 
transformations. The difficulty arises in connection with a large number of components of the reaction mixture (it can reach 300) when developing the kinetic model [2], a large number of stages of chemical transformations into which they can enter. Alternative may be reduced reaction mechanisms that are applicable to solve the problem and provide realistic description of the process.

Various approaches are proposed to simplify the detailed mechanisms. One of them is based on the grouping of individual hydrocarbons into groups according to various criteria, the most important of which are hydrocarbons and the number of carbon atoms in the structure of the molecules $[3,4]$. Another approach is based on the reduction of the detailed reaction mechanisms using the mathematical apparatus $[5,6]$, which is used in this work.

The computational technique for analyzing multistage chemical reactions based on its mathematical model and assessing the sensitivity of the model parameters to changes in kinetic and technological parameters were developed be the authors of the article [7, 8]. The sensitivity analysis of mathematical model is becoming increasingly important in connection with the development of computer technology and computer modeling of chemical-technological processes. The sensitivity coefficients of the model, which are the relationship between the input and output variables of the system, provide, on the one hand, important information for constructing, modifying and simplifying the model, and on the other hand, are of great importance for the analysis of the uncertainty of numerical modeling .

The assessment of the sensitivity of model to its parameters is used to solve the problem in its classical formulation, the ranking of input parameters by the degree of their influence on the change in the values of the output result. Sensitivity analysis is a standard approach for studying the influence of model parameters on such quantities as temperature, pressure, the ratio of the components of the reaction mixture in the field of hydrocarbon chemistry. This approach is acceptable in the narrow task of studying one and several parameters. When the task is to study the entire reaction mechanism, such an approach will turn out to be computationally expensive, inefficient and difficult to interpret the results of the study. Since it will be necessary to analyze matrices of sensitivity coefficients of large dimension, constructed for various conditions of the process (in particular, at different temperatures and contact times). In this regard, an urgent scientific task is the development of a methodology for the analysis of complex kinetic schemes and the reduction of kinetic models to sizes acceptable from the point of view of accuracy of description and ease of practical use.

The sensitivity analysis was carried out in order to identify the parameters that have the least effect on the catalytic reforming of gasoline under consideration in this paper. The reduced model can be obtained by identifying these parameters with fewer input parameters.

Scheme of transformations of catalytic reforming of gasoline. The scheme is based on the Iranshahi scheme [9]. The paraffin cracking reactions are represented by the total cracking reaction of each paraffin to final light paraffins containing 1-5 carbon atoms in the molecule. The cracking reactions of naphthenes (as well as paraffins) proceed to the final light hydrocarbons, i.e. with the destruction of the cyclic structure. The reactions of destruction of the cyclic structure of naphthenes are taken into account twice, and the formation of new naphthenes due to cracking of alkyl substituents is not taken into account. The model [10] contains cracking reactions of light paraffins 
(ethane, propane and butane), although these reactions are practically impossible under reforming conditions and do not affect the quality and quantity of the products obtained.

All the above disadvantages were eliminated in the model [11]. Paraffin cracking reactions and cracking reactions of alkyl substituents of naphthenes and aromatic hydrocarbons are presented separately and described by analogy with the Crane model [12]. Also added group components for each class of hydrocarbons containing 10 and 11 carbon atoms. Xylenes and ethylbenzene are combined into one group, since when reforming (the purpose of which is to obtain high-octane gasoline components). It is enough to know only their total content.

In the kinetic model [11], the individual components are combined into 37 groups belonging to the following classes: normal paraffins $\left(\mathrm{nP}_{\mathrm{i}}\right)$, iso-paraffins $\left(\mathrm{iP}_{\mathrm{i}}\right)$, five-membered naphthenes $\left(\mathrm{ACP}_{\mathrm{i}}\right)$, six-membered naphthenes $\left(\mathrm{ACH}_{\mathrm{i}}\right)$ and aromatic hydrocarbons $\left(\mathrm{A}_{\mathrm{i}}\right)$, where $i$ is the number of carbon atoms in the structure of the molecule. The final scheme includes 171 stages.

Mathematical model. The dimensions of the basic quantities were revised to account changes in the number of moles in reaction. The change in concentration $x_{i}$, expressed in mass fractions, is replaced by the molar consumption of the component $\mathrm{kmol} / \mathrm{h}$. The molar flow rate of the reaction mixture is formed from the molar flow rates of the components. The model requires accounting for changes in the molar flow rate of the mixture.

It is necessary to take into account the use of adiabatic reactors for carrying out reactions with a strong endothermic effect when developing a kinetic model of the process of catalytic reforming of gasoline. Due to the use of adiabatic reactors for reactions with strong heat absorption, a significant decrease in the temperature of the mixture is observed along the catalyst layer in the reactors. It is necessary to take into account the thermodynamic parameters of the reaction components to describe the nonisothermal nature of the process.

The mathematical model of catalytic reforming of gasoline, taking into account the change in the concentration of reagents, the change in the number of moles of the reaction mixture and the change in temperature of the mixture from the time of contact with the catalyst, has the form:

$$
\begin{gathered}
\frac{d x_{i}}{d \tau}=\sum_{i=1}^{I} v_{i j} \cdot w_{j}, i=1, \ldots, I \\
\frac{d F}{d \tau}=\sum_{i=1}^{I} \frac{d x_{i}}{d \tau} \\
\frac{d T}{d \tau}=\frac{\sum_{i=1}^{I} \Delta H_{T i}^{f} \cdot \frac{d x_{i}}{d \tau}}{\sum_{i=1}^{I} C_{p i}^{T} \cdot x_{i}} \\
w_{j}=k_{j}^{0} \exp \left(-\frac{E_{j}^{+}}{R T}\right) \cdot \prod_{j=1}^{J}\left(\frac{x_{i}}{F}\right)^{\left|\alpha_{i j}\right|}-k_{-j}^{0} \exp \left(-\frac{E_{j}^{+}}{R T}\right) \cdot \prod_{j=1}^{J}\left(\frac{x_{i}}{F}\right)^{\beta_{i j}} .
\end{gathered}
$$




$$
\begin{gathered}
\Delta H_{T_{i} i}^{f}=\Delta H_{298 i}^{f}+\int_{298}^{T} C_{p i}^{T} \cdot d T \\
C_{p i}^{T}=a_{i}+b_{i} T+c_{i} T^{2}+d_{i} T^{3}+e_{i} T^{4}
\end{gathered}
$$

with initial conditions: at $\tau=0, x_{i}(0)=x_{i}^{0}, \mathrm{~T}(0)=\mathrm{T}^{0}$, where $v_{i j}$ are stoichiometric coefficients of chemical transformation schemes, $J$ is the number of stages, $x_{i}$ is the molar flow rate of the $i$-th component, $(\mathrm{kmol} / \mathrm{h})$ participating in the reaction, $I$ is the number of components, $w_{j}$ is the speed of the $j$-th stage $\left(\mathrm{kmol} /\left(\mathrm{h}^{*} \mathrm{~kg}\right.\right.$ cat. $\left.)\right), E_{j}^{+}$and $E_{j}^{-}$are the activation energies of the direct and reverse reactions, respectively $(\mathrm{J} / \mathrm{mol}), \mathrm{R}$ is the gas constant equal to $8.31 \mathrm{~J} \mathrm{~mol}^{-1} \mathrm{~K}^{-1}, T$ is the temperature $(\mathrm{K}), \alpha_{i j}$ and $\beta_{i j}$ are the negative and positive elements of the matrix $\left(v_{i j}\right)$, respectively, $k_{j}^{0}$ and $k_{-j}{ }^{0}$ are the preexponential factors of the forward and reverse reactions, respectively ( $\mathrm{kmol} /(\mathrm{h} * \mathrm{~kg}$ cat. $)), \tau$ is the conditional contact time (kg cat.), $F$ is the molar flow rate $(\mathrm{kmol} / \mathrm{h}), \Delta H_{T_{i_{i}}}^{f}$ is the enthalpy of formation of the $i$-th component at temperature $T,(\mathrm{~J} / \mathrm{mol}), \Delta H_{T_{i}}^{f}$ is the enthalpy of formation of the $i$-th component at $298 \mathrm{~K},(\mathrm{~J} / \mathrm{mol})$, is the specific heat of the $i$-component at a temperature of $T$ $\mathrm{J} /\left(\mathrm{mol}^{*} \mathrm{~K}\right), a_{i}, b_{i}, c_{i}, d_{i}, e_{i}$ are the coefficients of the temperature dependence of the heat capacity of the $i$-component.

It is possible to estimate the reaction time by changing the productivity on the base of the mathematical description (1)-(6), (molar flow rate at the initial time) and the amount of loaded catalyst. In the system of differential equations (1)-(6), a change in the molar flow rate of the mixture without changing the composition does not lead to a change in the rates of the chemical reaction, since the concentration remains unchanged. Thus, halving the molar flow rate causes the effect of doubling the reaction time. In accordance with the changes in the mathematical model, one can take into account the contact time of the reaction mixture with the catalyst, which is the function of its flow rate and the amount of loaded catalyst.

Sensitivity analysis of mathematical model. The solution of the tasks in the framework of sensitivity analysis contains the following main steps:

- determination of the list of key calculation parameters for which sensitivity analysis is carried out;

- determination of the size of the intervals of variation and the nature of the laws of distribution within these intervals on the basis of the level of knowledge about physical phenomena;

- determination of the required number of combinations of variable parameters (the number of calculations performed) to ensure statistical reliability of the results;

- execution of calculations;

- processing and analysis of the calculated data obtained after carrying out sets of numerical analyzes.

Many methods have been developed for determining the sensitivity of output parameters to input [13-15]. The global Sobol method was used in this work to obtain a reduced model of catalytic reforming of gasoline. The global sensitivity coefficient characterizes the contribution of the variance $D_{i}$ of an individual parameter $k_{j}$ to the total variance $D$ of the analyzed function. To take into account 
the influence of the variable $k_{j}$, full global sensitivity indices $S_{i}^{\text {tot }}$, proposed by A. Saltelli are used [16]. The calculation of this indicator can be based on the calculation of the variance $D_{\text {-i }}$ obtained because of changing all the parameters except for the $k_{j}$ parameter:

$$
S_{i}^{t o t}=S_{i}+\sum_{j \neq i} S_{i j}+\ldots=\frac{D-D_{-i}}{D} .
$$

For analysis, aromatic hydrocarbons $\mathrm{A}_{6}-\mathrm{A}_{11}$ were considered, isoparaffins $\mathrm{iP}_{5}-\mathrm{iP}_{7}$, alkyl cyclopentanes $\mathrm{ACP}_{6}, \mathrm{ACP}_{7}$ and alkyl cyclohexanes $\mathrm{ACH}_{6}-\mathrm{ACH}_{8}$. The rest of the article will call these substances significant.

The model parameters to be identified were determined by a global analysis of the sensitivity of the functional of the mathematical model to the variation of the rate constants of the stages. Functional is an additionally introduced function that characterizes the measure of proximity of calculated values according to the existing and modified reaction schemes by disturbing its parameters at different time instants:

$$
F=\sum_{i=1}^{I} \sum_{j=1}^{J}\left(x_{i j}^{s h 1}-x_{i j}^{s h 2}\right)^{2}
$$

where $x_{i j}^{s h l}$ are calculated values of the concentrations of substances obtained according to the original scheme; $x_{i j}^{s h 2}$ are calculated values of the concentrations of substances obtained by changing (disturbing) the parameters in the circuit. As the initial values of the concentrations of substances $x_{i j}{ }^{\text {sh }}$ with which the comparison was carried out, we took the values obtained by a numerical solution of system (1)-(6) with the initial data.

The full global $S_{i}^{\text {tot }}$ sensitivity indices are used to rank the effect of all the rate constants of the stages on the change in the functional values, which were calculated using formula (7). Integrals of high multiplicity for determining dispersions were calculated by the quasi-Monte Carlo method. Different values of the rate constants were generated ( $2^{14}$ different sets) within a given range and, using dispersion, we evaluated how the variation of the constants affects the change in the functional. The constant of each stage varied within $5 \%$ of its value. It was assumed that the rate constants are independent of each other. Since there was no information about the distribution of input parameters, the parameter values for calculating the sensitivity coefficients were selected from a uniform distribution.

The results of the study. The results of reduction depend on many factors [7], including the choice of stage selection criterion. The values of the global sensitivity coefficients are normalized and can take values from zero to unity. The greater the sensitivity coefficient, the more important is the inclusion of this stage in the process scheme. The reduced reaction scheme includes only those stages for which the sensitivity coefficient is greater than a certain given number (threshold value). By setting this or that value or a set of values for the coefficients, it is possible to determine the degree of simplification of the scheme and, accordingly, the accuracy of the process description by the reduced scheme. In this problem, the stages were ranked by decreasing functional values, and the criterion for reduction was as follows: the relative deviation of the calculated values of the concentrations of significant reaction substances and temperature from detailed and reduced schemes should not exceed $5 \%$. 
Fig. 1 shows the temperature and concentration profiles of some substances. Gray vertical lines show the separation of the reactor block into three reactors. The applicability of the reduced mechanism was tested by comparing key features such as adiabatic temperature and component concentration distribution. Comparison was carried out with the results of calculations according to a detailed scheme. The reduced scheme provides quite satisfactory agreement both in temperature profiles and in concentration profiles of significant substances.
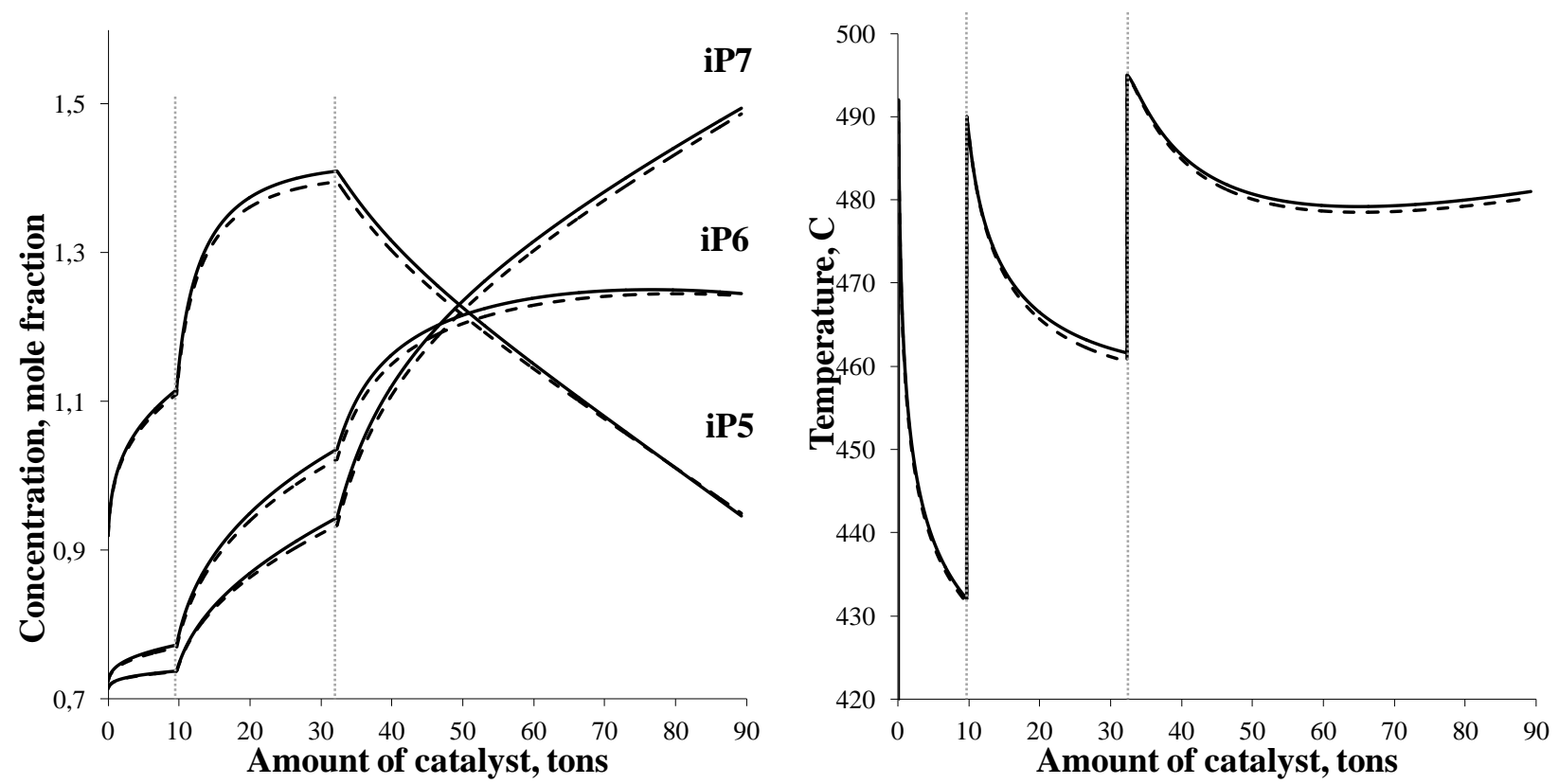

Fig. 1. Comparing the concentrations of substances and temperature (solid line shows the calculations according to the detailed scheme, dashed line shows the calculations according to the reduced scheme).

An analysis of the sensitivity of the functional model showed a low significance of the stages:

$$
\mathrm{ACH}_{11} \rightarrow \mathrm{nP}_{11}, \mathrm{ACH}_{10} \rightarrow \mathrm{nP}_{10}, \mathrm{ACH}_{9} \rightarrow \mathrm{nP}_{9}, \mathrm{ACH}_{8} \rightarrow \mathrm{nP}_{8}, \mathrm{ACH}_{7} \rightarrow \mathrm{nP}_{7} .
$$

Because the rate of the reverse reaction is much lower than the aromatization reactions of naphthenes, the overwhelming majority of the starting materials of these reactions will be spent on the dehydrogenation (aromatization) reactions of naphthenes. These stages can be discarded.

The similar situation with the stages presented below, taking into account the fact that the starting materials of these reactions will be spent on naphthenes isomerization reactions:

$$
\begin{gathered}
\mathrm{ACP}_{11} \rightarrow \mathrm{nP}_{11}, \mathrm{ACP}_{10} \rightarrow \mathrm{nP}_{10}, \mathrm{ACP}_{9} \rightarrow \mathrm{nP}_{9}, \mathrm{ACP}_{8} \rightarrow \mathrm{nP}_{8}, \mathrm{ACP}_{7} \rightarrow \mathrm{nP}_{7} ; \\
\mathrm{ACH}_{11} \rightarrow \mathrm{ACP}_{11}, \mathrm{ACH}_{10} \rightarrow \mathrm{ACP}_{10}, \mathrm{ACH}_{9} \rightarrow \mathrm{ACP}_{9}, \mathrm{ACH}_{8} \rightarrow \mathrm{ACP}_{8} .
\end{gathered}
$$

For the same reasons, you can abandon the group of the following stages:

$$
\begin{aligned}
\mathrm{ACH}_{11} & \rightarrow \mathrm{iP}_{11}, \mathrm{ACH}_{10} \rightarrow \mathrm{iP}_{10}, \mathrm{ACH}_{9} \rightarrow \mathrm{iP} 9, \mathrm{ACH}_{8} \rightarrow \mathrm{iP}_{8}, \mathrm{ACH}_{7} \rightarrow \mathrm{iP}_{7} ; \\
\mathrm{ACP}_{11} & \rightarrow \mathrm{iP}_{11}, \mathrm{ACP}_{10} \rightarrow \mathrm{iP}_{10}, \mathrm{ACP}_{9} \rightarrow \mathrm{iP}_{9}, \mathrm{ACP}_{8} \rightarrow \mathrm{iP}_{8}, \mathrm{ACP}_{7} \rightarrow \mathrm{iP}_{7} .
\end{aligned}
$$

The sensitivity analysis of the functional of the model showed a low significance of the stages $\mathrm{nP}_{11} \rightarrow \mathrm{iP}_{11}$ и $\mathrm{iP}_{11} \rightarrow \mathrm{nP}_{11}$. Rather, it is associated with a low content of starting components. In the case under consideration, these stages can be rejected; the concentration of the starting materials should serve as a criterion for failure. 
Refusal from the following stages is explained by low concentrations of reacting components: $\mathrm{nP}_{11} \rightarrow \mathrm{nP}_{10}+\mathrm{nP}_{1}, \mathrm{nP}_{11} \rightarrow \mathrm{nP}_{9}+\mathrm{nP}_{2}, \mathrm{nP}_{11} \rightarrow \mathrm{nP}_{8}+\mathrm{nP}_{3}, \mathrm{nP}_{11} \rightarrow \mathrm{nP}_{7}+\mathrm{nP}_{4}$,

$$
\begin{gathered}
n P_{11} \rightarrow n P_{6}+n P_{5} ; \\
n P_{5} \rightarrow n P_{4}+n P_{1}, n_{5} \rightarrow n P_{3}+n P_{2}, \\
\mathrm{PP}_{11} \rightarrow \mathrm{iP}_{10}+n P_{1}, \mathrm{iP}_{11} \rightarrow \mathrm{iP}_{9}+\mathrm{nP}_{2}, \mathrm{iP}_{11} \rightarrow \mathrm{iP}_{8}+n \mathrm{nP}_{3}, \mathrm{iP}_{11} \rightarrow \mathrm{iP}_{7}+\mathrm{nP}_{4}, \mathrm{iP}_{11} \rightarrow \mathrm{iP}_{6}+\mathrm{nP}_{5}
\end{gathered}
$$

The stages $\mathrm{nP}_{10} \rightarrow \mathrm{nP}_{9}+\mathrm{nP}_{1}, \mathrm{nP}_{10} \rightarrow \mathrm{nP}_{8}+\mathrm{nP}_{2}$ have many similarities. The same components act as starting reactants. If you look at the kinetic parameters, you can see that the reaction rate $\mathrm{nP}_{10} \rightarrow$ $\mathrm{nP}_{8}+\mathrm{nP}_{2}$ higher reaction rate $\mathrm{nP}_{10} \rightarrow \mathrm{nP}_{9}+\mathrm{nP}_{1}$. The reactions $\mathrm{nP}_{10} \rightarrow \mathrm{nP}_{8}+\mathrm{nP}_{2}$ do not significantly affect the result, then the reaction $\mathrm{nP}_{10} \rightarrow \mathrm{nP}_{9}+\mathrm{nP}_{1}$ also had to be excluded. As a result, both reactions can be refused.

According to the results of the analysis, the stages are also subject to exclusion

$$
\begin{aligned}
\mathrm{ACH}_{11} & \rightarrow \mathrm{ACH}_{10}+\mathrm{nP}, \mathrm{ACH}_{11} \rightarrow \mathrm{ACH}_{9}+\mathrm{nP}_{2}, \mathrm{ACH}_{11} \rightarrow \mathrm{ACH}_{8}+\mathrm{nP} ; \\
\mathrm{ACH}_{10} & \rightarrow \mathrm{ACH}_{9}+\mathrm{nP}_{1}, \mathrm{ACH}_{10} \rightarrow \mathrm{ACH}_{8}+\mathrm{nP}_{2}, \mathrm{ACH}_{10} \rightarrow \mathrm{ACH}_{7}+\mathrm{nP}_{3} ; \\
\mathrm{ACH}_{8} & \rightarrow \mathrm{ACH}_{7}+\mathrm{nP}_{1} ; \\
\mathrm{ACP}_{11} & \rightarrow \mathrm{ACP}_{10}+\mathrm{nP}_{1}, \mathrm{ACP}_{11} \rightarrow \mathrm{ACP}_{10}+\mathrm{nP}_{1}, \mathrm{ACP}_{11} \rightarrow \mathrm{ACP}_{9}+\mathrm{nP}_{2}, \\
\mathrm{ACP}_{11} & \rightarrow \mathrm{ACP}_{8}+\mathrm{nP}_{3} ; \\
\mathrm{ACP}_{10} & \rightarrow \mathrm{ACP}_{9}+\mathrm{nP}_{1}, \mathrm{ACP}_{10} \rightarrow \mathrm{ACP}_{8}+\mathrm{nP}_{2}, \mathrm{ACP}_{10} \rightarrow \mathrm{ACP}_{7}+\mathrm{nP}_{3} .
\end{aligned}
$$

From a chemical point of view, one can explain the significant predominance of dehydrogenation (aromatization) reactions of naphthenes over the reactions given above.

The sensitivity analysis also showed the low significance of the following stages:

$$
\mathrm{nP} \mathrm{ACH}_{11} \rightarrow \mathrm{ACH}_{11}, \mathrm{nP}_{10} \rightarrow \mathrm{ACH}_{10}, \mathrm{nP}_{11} \rightarrow \mathrm{ACH}_{11}, \mathrm{nP}_{11} \rightarrow \mathrm{ACP}_{11}, \mathrm{iP}_{11} \rightarrow \mathrm{ACH}_{11} \text {. }
$$

Although the influence of the reactions is not significant, we cannot refuse these reactions, since they are basic in terms of the mechanism. A probable reason for the insignificant effect of these reactions is the low concentration of the reacting components. As a result, the rejection of these reactions is not desirable.

Conclusion. The sensitivity analysis of the mathematical model of catalytic reforming of gasoline is carried out. The least influential reaction stages are determined that do not affect the general dynamics of changes in the concentrations of significant reaction substances. The shortened reaction model is obtained by excluding these stages. Based on the results of the reduction of the model, it is possible to raise the question of deleting not only these reactions, but also the rejection of two group components: $\mathrm{nP}_{11}$ and $\mathrm{iP}_{11}$, with the addition of their content to the components $\mathrm{nP}_{10}$ and $\mathrm{iP}_{10}$, respectively. It is possible to reduce the system of differential equations by two equations. The reduced model does not provide the amount of information that is available in the calculation according to the detailed scheme, but allows to obtain satisfactory results for significant substances. The described functional sensitivity analysis procedure can be applied to a different set of reaction substances and with other criteria, if necessary.

\section{References}

1. Zaynullin, R.Z. Vozmozhnyye puti modernizatsii reaktornogo bloka kata-liticheskogo riforminga na osnove kineticheskoy modeli / R.Z. Zaynullin, K.F. Koledina, A.F. Akhmetov, I.M. Gubaydullin // Elektronnyy nauchnyy zhurnal Neftegazovoye delo. - 2018. - № 6. - P. 78-97. 
2. Stijepovic, M.Z. Development of a kinetic model for catalytic reforming of naphtha and parameter estimation using industrial plant data / M.Z. Stijepovic, A.V. Ostojic, I. Milenkovic, P. Linke // Energy Fuels. - 2009. - № 23. - P. 83.

3. Stadnichenko, O.A. Radical mechanism for the gas-phase thermal decomposi-tion of propane / O.A. Stadnichenko, L.F. Nurislamova, N.V. Masyuk, Vl.N., Snytnikov V.N. Snytnikov // Reaction Kinetics, Mechanisms and Catalysis. - 2018. - V. 123. - Is. 2. - P. 607-624.

4. Qin, Z. Combustion chemistry of propane: A case study of detailed reaction mechanism optimization / Z. Qin, V.V. Lissianski, H. Yang, W.C. Gardiner, S.G. Davis, H. Wang // Proceedings of the Combustion Institute. - 2000. - V. 28. - Is. 2. - P. 1663-1669.

5. Lu, T. Toward accommodating realistic fuel chemistry in large-scale computa-tions / T. Lu, C.K. Law // Progress in Energy and Combustion Science. - 2009. - V. 35. - I. 2. - P. 192-215.

6. Law, C. K. Development of comprehensive detailed and reduced reaction mechanisms for combustion modeling / C.K. Law, C.J. Sung, H. Wang, T.F.Lu. // AIAA Journal. - 2003. - V. 41. - N. 9. - P. 1629-1646.

7. Nurislamova, L.F. Mechanism reduction of chemical reaction based on sensi-tivity analysis: development and testing of some new procedure / L.F. Nuris-lamova, I.M. Gubaydullin // Journal of Mathematical Chemistry. - 2017. - V. 55. - № 9. - P. 1779-1792.

8. Safiullina, L.F. Computational aspects of simplification of mathematical mod-els of chemical reaction systems / L. F. Safiullina, I. M. Gubaydullin, R. M. Uz-yanbaev, A. E. Musina // Journal of Physics: Conference Series. - 2019. - V. 1368.

9. Rahimpour, M. R. Progress in Catalytic Naphtha Reforming Process: A Re-view / M. R. Rahimpour, M. Jafari, D. Iranshahi //Applied Energy. - 2013. - №109. - P. 79-93.

10. Iranshahi, D. Modeling and simulation of a novel membrane reactor in a con-tinuous catalytic regenerative naphtha reformer accompanied with a detailed de-scription of kinetics / D. Iranshahi, H. Amiri, M. Karimi // EnergyFuels. - 2013. - No. 27. - P. 4048-4070.

11. Zainullin, R. Z. Kinetics of the Catalytic Reforming of Gasoline / R. Z. Zainul-lin, K. F. Koledina, A. F. Akhmetov, I. M. Gubaidullin // Kinetics and Catalysis. - 2017. - Vol. - 58. - № 3. - P. 279 288.

12. Khimiya kataliticheskikh protsessov /B. Geyts, Dzh. Kettsir, G. Shuyt. - M.: Mir, 1981. - P. 551.

13. Ikonen, T. The importance of input interactions in the uncertainty and sensi-tivity analysis of nuclear fuel behavior / T. Ikonen, V. Tulkki // Nuclear Engineer-ing and Design. - 2014. - V. 275. - P. 229-241.

14. Tomlin, A.S. Mathematical tools for the construction, investigation and re-duction of combustion mechanisms / A.S. Tomlin, T. Turanyi, M.J. Pilling // Comprehensive chemical kinetics. - 1997. - T. 35. - P. 293-437.

15. Miles, S.O. Simplification of mathematical models of chemical reaction sys-tems / S.O. Miles, M.L. Mavrovouniotis // Chemicals Reviews. - 1998. - T. 98. - No.2. - P. 391-408.

16. Saltelli, A. Sensitivity analysis for chemical models / A. Saltelli, M. Ratto, S. Tarantola, F. Campolongo // Chemical Reviews. - 2005. - T. 105. - N 7. - P. 2811-2828.

Authors:

Liana F. Safiullina, Cand.Sci. (Phys.-Math.), Researcher of Research Sector, Bashkir State University (Validy Str., 32, Ufa, Russian Federation). 
Irek M. Gubaydullin, Dr.Sci. (Phys.-Math.), associate professor, professor of the Oil and Gas Technology Department, Ufa State Petroleum Technological University (1 Kosmonavtov St., Ufa, Russian Federation).

Kamila F. Koledina, Cand.Sci. (Phys.-Math.), associate professor, associate professor of the Mathematics Department, Ufa State Petroleum Technological University (1 Kosmonavtov St., Ufa, Russian Federation).

Ravil' Z. Zaynullin, assistant of the Oil and Gas Technology Department, Ufa State Petroleum Technological University, (1 Kosmonavtov St., Ufa, Russian Federation). 


\section{Анализ чувствительности математической модели каталитического риформинга бензина}

\section{Л. Ф. Сафиуллина ${ }^{12}$, И. М. Губайдуллин ${ }^{23}$, К.Ф. Коледина ${ }^{23}$, Р. З. Зайнуллин ${ }^{2 * *}$}

${ }^{1}$ Башкирский государственный университет, г. Уфа, Российская Федерация

${ }^{2}$ Уфимский государственный нефтяной технический университет, г. Уфа, Российская Федерация

${ }^{3}$ Институт нефтехимии и катализа, г. Уфа, Российская Федерация

Для изучения одного из важнейших процессов нефтепереработки - каталитического риформинга, требуется детализированная кинетическая модель. При разработке кинетической модели возникает сложность в связи с большим количеством компонентов реакционной смеси и большим количеством стадий химических превращений. Альтернативой могут быть сокращенные механизмы реакций, которые применимы для решения задачи и обеспечивают реалистичное описание процесса. В данной работе для получения сокращенного механизма используется разработанная авторами методика анализа чувствительности математической модели. Схема превращений каталитического риформинга бензина, предложенная авторами, включает в себя 171 стадию. Индивидуальные компоненты объединены в 37 групп, относящихся к следующим классам: нормальные парафины, изо-парафины, пятичленные нафтены, шестичленные нафтены и ароматические углеводороды. Представлена математическая модель каталитического риформинга бензина, учитывающая изменение концентраций реагентов, изменение количества молей реакционной смеси и изменение температуры смеси от времени контакта с катализатором. В данной работе для получения редуцированной модели каталитического риформинга бензина использовался глобальный метод Соболя. Параметры модели, подлежащие исключению, определялись путем глобального анализа чувствительности функционала математической модели к вариации констант скоростей стадий. Разработана новая методика анализа сложных кинетических схем и редуцирования кинетических моделей до размеров, приемлемых с точки зрения точности описания и простоты практического использования. Выявлены наименее влиятельные стадии каталитического риформинга бензина. Исследовано влияние исключения данных стадий на кинетику процесса с химической точки зрения. Предложена редуцированная схема каталитического риформинга бензина. Редуцированная схема обеспечивает вполне удовлетворительное согласие как по профилям температуры, так и по профилям концентраций значимых веществ. Проведен анализ чувствительности математической модели каталитического риформинга бензина. Определены наименее влиятельные стадии реакции, не влияющие на общую динамику изменения концентраций значимых веществ реакции. Получена сокращенная модель реакции исключением данных стадий.

Ключевые слова: каталитический риформинг, математическая модель, химическая кинетика, анализ чувствительности, редуцированная модель.

\footnotetext{
**E-mail: Nurislamova_LF@mail.ru, IrekMars@mail.ru, koledinakamila@mail.ru , zaynullin_ravil@ outlook.com
} 


\section{Авторы:}

Лиана Сафиуллина, кандидат физико-математических наук, научный сотрудник, Башкирский государственный университет (ул. Валиды, 32, Уфа, Российская Федерация).

Ирек Губайдуллин, доктор физико-математических наук, доцент, профессор кафедрытехнологии нефти и газа Уфимский государственный нефтяной технический университет (ул. Космонавтов, 1, Уфа, Российская Федерация).

Камила Коледина, кандидат физико-математических наук, доцент кафедры математики Уфимского государственного нефтяного технологического университета (ул. Космонавтов, 1, Уфа, Российская Федерация).

Равиль Зайнуллин, ассистент кафедры нефтегазовой технологии, Уфимский государственный нефтяной технический университет (ул. Космонавтов, 1, Уфа, Российская Федерация). 